\title{
Erratum to: Immunologic hierarchy, class II MHC promiscuity, and epitope spreading of a melanoma helper peptide vaccine
}

\author{
Yinin Hu • Gina R. Petroni · Walter C. Olson • Andrea Czarkowski • \\ Mark E. Smolkin • William W. Grosh • Kimberly A. Chianese-Bullock • \\ Craig L. Slingluff Jr.
}

Published online: 26 August 2014

(C) Springer-Verlag Berlin Heidelberg 2014

Erratum to: Cancer Immunol Immunother (2014)

63:779-786

DOI 10.1007/s00262-014-1551-x

Unfortunately, the published version of this article did not include vital grant information. The relevant details are given below.

Acknowledgments This work was supported in part by Grants from the National Institutes of Health/National Cancer Institute: NIH R21 CA105777 (to Craig L. Slingluff), T32 CA163177 (to Yinin Hu), and U01 CA178846 (to Craig L. Slingluff).

The online version of the original article can be found under doi:10.1007/s00262-014-1551-x.

Y. Hu $(\bowtie) \cdot$ W. C. Olson · K. A. Chianese-Bullock ·

C. L. Slingluff Jr.

Department of Surgery/Division of Surgical Oncology, University of Virginia Health System, PO Box 800679, Charlottesville, VA 22908-0679, USA

e-mail: yh9b@virginia.edu

G. R. Petroni · M. E. Smolkin

Department of Public Health Sciences, University of Virginia

Health System, Charlottesville, VA 22908, USA

\section{A. Czarkowski}

Cancer Center, University of Virginia Health System,

Charlottesville, VA 22908, USA

W. W. Grosh

Department of Medicine/Division of Hematology-Oncology, University of Virginia Health System, Charlottesville, VA 22908 , USA 